EGU Stephan Mueller Special Publication Series, 3, 1-7, 2002

(C) European Geosciences Union 2002

\title{
Introduction
}

\section{Neotectonics and surface processes: the Pannonian Basin and Alpine/Carpathian System}

\author{
Editors: S. A. P. L. Cloetingh (Amsterdam), F. Horváth (Budapest), G. Bada (Amsterdam), A. C. Lankreijer (Amsterdam)
}

\section{The Pannonian Basin-Alpine/Carpathian System as a key natural laboratory for neotectonic studies}

This volume contains a series of selected papers on the interplay of lithospheric deformation and surface processes in the Pannonian basin and Alpine/Carpathian System (PBACS). The contributions summarise the most recent results of multidisciplinary efforts to better understand problems of increasing societal importance: neotectonics, surface processes and related natural hazard. The PBACS in Central and Eastern Europe is an area of mainly low and medium tectonic activity where traditionally not much attention has been paid to these topics. New observations and concepts of present-day deformation in intraplate regions, formerly believed to be seismotectonically inactive, indicate a significant level of neotectonic activity, both seismic and aseismic leading to significant deformation of the Earth's crust. Understanding of the deformation distribution both in space and time, and assessment of the impact of aseismic (vertical motions, landslides) as well as seismic hazard are important issues of significant societal relevance.

The Pannonian Basin and Alpine/Carpathian System provides a key natural laboratory for the development of a new generation of models for ongoing orogeny and its effect on continental landscape evolution. The PBACS represents one of the best documented sedimentary basins of the world (see Royden and Horváth, 1988; Horváth, 1993; Neubauer et al., 1997; Horváth and Tari, 1999; Tari et al., 1999; Cloetingh et al., 1993, 2001) located at the transition of the western European lithosphere and eastern European platform. The Pannonian basin is one of the classical back-arc basins (Bally and Snelson, 1980) where first generation stretching models and subsequent modifications (Sclater et al., 1982) have been validated, whereas the Carpathian belt has many characteristics of a classical foreland and fold-and-thrust belt. The degree of intensity in which different segments of the Pannonian Basin-Carpathian System have been studied utilising modern sedimentary basin concepts varies significantly over the system. Whereas the central parts of the Pannonian basin
(Tari, 1994; Csontos, 1995; Fodor et al., 1999; Sacchi et al., 1999) and various segments of the Carpathian arc have been studied in great detail (e.g. Matsenco et al., 1997a; Zoetemeijer et al., 2001), this has not been the case for major areas in the Dinarides and the north-eastern part of the Carpathians (see Cloetingh et al., 2001).

Latest research efforts have focused on the interplay of extension and compression in continental collision and have established solid understanding of lithospheric processes through a combination of various modelling studies (e.g. Szafián et al., 1997; Lankreijer et al., 1999; Van Balen et al., 1999; Willingshofer et al., 1999; Bada et al., 2001; Huismans et al., 2001). Models have been constrained by the results of integrated basin analysis in the Pannonian basin (e.g. Vakarcs et al., 1994; Lankreijer et al., 1995; Sacchi et al., 1999; Juhász et al., 1999), by thermochronology (Sanders et al., 1999), and structural field studies in the Pannonian basin and the surrounding Carpathian belt (e.g. Fodor et al., 1999; Maţenco et al., 1997a; Maţenco and Bertotti, 2001).

The Pannonian basin went through a multistage tectonic evolution from a syn-rift to a post-rift phase during Early to Late Miocene times where back-arc extension was coupled with subduction dynamics in the Carpathian orogenic arc system (Royden, 1988). The basin system, the hottest in continental Europe, has been proposed to have rapidly gone through a temporal transition of passive to active rifting simultaneously with the climax of compression in the Carpathian arc (Huismans et al., 2001). Previous work (Horváth and Cloetingh, 1996) has established the importance of late-stage, late Pliocene through Quaternary compression inside the Pannonian basin as well, explaining its anomalous uplift and subsidence, and intraplate seismicity (Fig. 1). Flexural modelling and the reconstruction of uplift and erosion history in the Carpathians has elucidated for the first time the complex interplay of flexural downloading during collision (Zoetemeijer et al., 1999), followed by unroofing by unflexure and isostatic rebound (Sanders et al., 1999). This resulted in the formation and deformation of fault-controlled depo-centres that controlled mass distribu- 

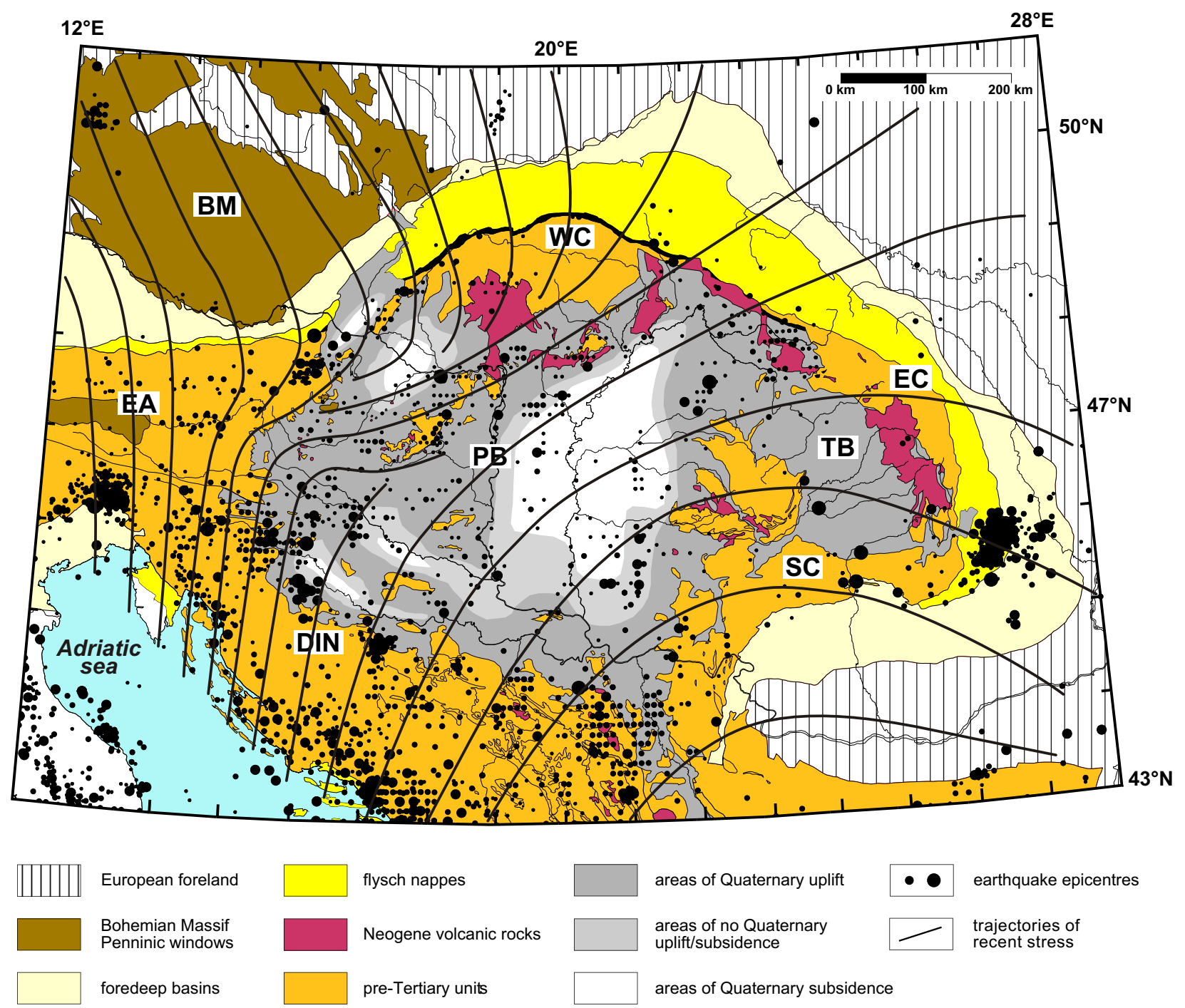

Fig. 1. Neotectonic setting of the Pannonian basin and Alpine/Carpathian System with major tectonic units, seismicity distribution, Quaternary vertical deformation and the present-day maximum horizontal stress trajectories. BM: Bohemian Massif; DIN: Dinarides; EA: Eastern Alps; EC: Eastern Carpathians; PB: Pannonian basin; SC: Southern Carpathians; TB: Transylvanian basin; WC: Western Carpathians.

tion of sediments between the Carpathian arc, the eastern European platform and the Black Sea.

The intrinsic weakness of the Pannonian basin lithosphere (Lankreijer et al. 1999), as well as its tectonic setting landlocked in the interior of the Carpathian arc, has made it a very sensitive recorder of changes in lithospheric stress induced by near-field and far-field plate boundary processes (Bada et al., 1998, 2001). High quality constraints exist on presentday and paleostress fields in the lithosphere as a result of kinematic studies of stress field indicator data (Fodor et al., 1999), earthquake focal mechanism studies, and the analyses of borehole breakouts (Gerner et al., 1999). These studies have demonstrated a close relationship between the timing and nature of stress changes in the extensional basin on one hand and the structural episodes in the surrounding thrust belts on the other hand, pointing to an intrinsic mechanical coupling between the orogen and the basin (e.g. Cloetingh and Lankreijer, 2001).

Over the last few years, much attention has been focusing on the spatial and temporal variations in thrusting along the Carpathian arc (Ellouz and Roca, 1994) and its relationship to migrating foredeep depo-centres (Meuelenkamp et al., 1996), changes in foreland basin geometry and lateral variations of flexural rigidity (Zoetemeijer et al., 1999). A general feature of all the flexural modelling studies carried out for the Carpathian system so far (e.g. Zoetemeijer et al., 1999; Maţenco et al., 1997b) is the inferred low rigidity of the platform lithosphere downbending under the Carpathians, with effective elastic thickness (EET) estimates consistently below predictions from rheological models of corresponding thermotectonic ages (Cloetingh and Burov, 1996). Flexural studies constrained by gravity (e.g. Szafián et al., 


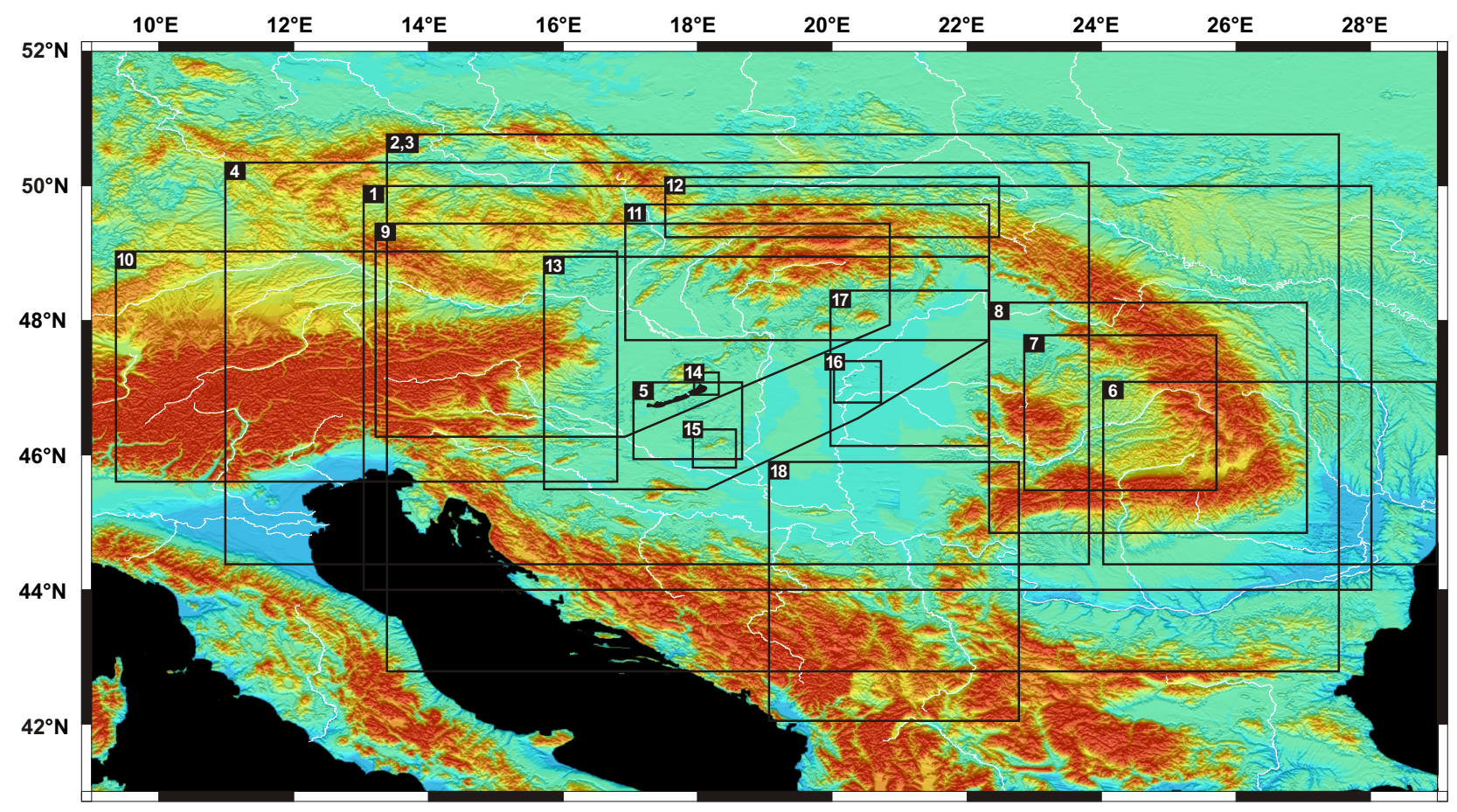
1: Tóth et al.
4: Grenerczy et al.
7: Ciulavu et al.
10: Székely et al.
13: Síkhegyi
16: Lörincz et al.
2: Lenkey et al.
5: Sacchi \& Horváth
8: Sanders et al.
11: Kováč et al.
14: Lopes Cardozo et al.
17: Timár \& Rácz
3: Huismans et al.
6: Wenzel et al.
9: Dunkl \& Frisch
12: Zuchiewicz et al.
15: Csontos et al.
18: Marović et al.

Fig. 2. Map of area for location of papers presented in this volume.

1999) have also drawn further attention to the importance of flexural unroofing of the Carpathian mountain chain and its foredeep. Quantitative subsidence analyses of a number of basins at the rim of the Pannonian basin including the Styrian basin (Sachsenhofer et al., 1997), the Austrian German Molasse basin (Andeweg and Cloetingh, 1998), the Vienna and East Slovak basins (Lankreijer et al., 1995) and the Transylvanian basin (Ciulavu, 1999) have demonstrated a major uplift of several hundred meters starting from Mio-Pliocene time onward. These findings have recently been corroborated by results from fission track studies in the Romanian Carpathians, demonstrating up to $5 \mathrm{~km}$ of erosion with a systematic migration from the north-western and south-western part of the Romanian Carpathians, uplifted since $12 \mathrm{Ma}$, towards the bend area where uplift and erosion was initiated from $4 \mathrm{Ma}$ onward (Sanders et al., 1999). These rapid differential motions of the rim of the Pannonian basin and the Carpathians have obviously important implications for sediment supply to the depo-centres as well as for hydrocarbon habitat (Horváth and Tari, 1999). These findings can now be connected with results of seismic tomography highlighting the development of hot mantle under the Pannonian basin and imaging the presence of late-stage detachment of the lithosphere in the Vrancea area (Wenzel et al., 1998; Wortel and Spakman, 2000).

\section{Highlights of latest developments}

With the establishment of a quantitative lithospheric framework and the set up of a strong network of collaboration with key institutes active in the area, major efforts have been started to tackle outstanding questions on the processes controlling landform evolution and natural hazards during the last stage of evolution of the Pannonian Basin and Alpine/Carpathian System. This involves a dedicated effort through an interpretation of existing data, new data acquisition, deployment of analytical facilities and process-oriented modelling. The 18 papers presented in this volume address various aspects of multidisciplinary research on the feedback mechanisms between lithospheric deformation and surface processes. The collection of contributions cover nearly the entire PBACS from the Eastern Alps through the Pannonian basin to the foredeep of the Eastern Carpathians (Fig. 2).

\subsection{Lithosphere dynamics of the PBACS}

The first set of five papers in this volume focuses on various aspects of lithosphere dynamics in the Pannonian Basin and Alpine/Carpathian System. The papers highlight recent developments in modelling and the constraints on these models by multidisciplinary data sets collected in the last few years. Tóth et al. review the existing seismicity data for the entire 
Pannonian region. Their data base contains more than 20000 historical and instrumentally recorded earthquakes. In addition, a review is given of the stress data derived from 190 focal mechanism solutions for individual earthquakes. These data demonstrate high level of activity in the Dinarides and the Carpathians, including the Vrancea area of the southeastern Carpathians. Hypocentres in the area are in general in the uppermost $20 \mathrm{~km}$ of the crust, with intermediate seismicity in the Vrancea area down to $200 \mathrm{~km}$ depth. In the Pannonian basin most events are located at depths between 6-15 km, with strike-slip and thrust faulting as the dominant way of stress release. Lenkey et al. focus on the connection of geothermics of the Pannonian basin and neotectonics. The authors present a heat flow map of the area and point out that the high heat flow in the centre of the Pannonian basin is consistent with Middle Miocene extension and considerable thinning of the lithosphere, whereas observed late-stage uplift in the peripheral areas supports a scenario where thermal subsidence has been overprinted by intraplate compression. Huismans et al. review feedback relationships between passive far-field induced extension and active mantle upwelling following a phase of passive extension in the context of the mechanisms proposed for the formation of the Pannonian basin. These authors present finite-element modelling developed to examine the dynamic interplay of far field driven passive extension and active thinning of the mantle lithosphere by convective upwelling. These models support a scenario with a first phase of passive lithospheric thinning under the Pannonian basin, followed by a second phase of late syn-rift to post-rift active mantle lithospheric thinning. Grenerczy et al. present an overview of constraints on present crustal deformation patterns in the Pannonian-Carpathian-Dinarides region obtained from space geodesy. Following a synthesis of GPS campaigns, the authors analyse the available data. Subsequently a comparison is made of the velocities derived from space geodesy with existing models. This work supports a scenario in which the northward moving Adriatic promontory squeezes out the Alpine-North Pannonian Unit to the east from between the Bohemian Massif and Adria, with the eastward escape probably absorbed in the central part of the Pannonian basin. Sacchi and Horváth highlight the importance of a reliable chronostratigraphic framework for tectonic interpretation of the evolution of the Pannonian basin. These authors propose the introduction of a new stage/sub-stage in the Late Miocene series of the Central Paratethys System. This new Transdanubian stage has been defined by means of biostratigraphy, lithostratigraphy, magnetostratigraphy, sequence stratigraphy and absolute age dating.

\subsection{The Carpathian bend zone and the Transylvanian basin}

The next three papers focus on the area of Carpathian bend zone and the Transylvanian basin. The contribution by Wenzel et al. presents a synthesis of geological evidence, new seismic tomographic inversions and seismicity data of the Vrancea area in the SE Carpathians. These authors argue in favour of a scenario on ongoing plate break-off processes after subduction and collision ceased $10 \mathrm{Ma}$ ago. Wenzel et al. discuss the implications of a detected high-velocity body visible between 70 and $350 \mathrm{~km}$ depth and the cluster of intermediate-depth seismicity in its upper part. Ciulavu et al. present seismic lines to highlight the Cenozoic structural pattern of the Transylvanian basin and the north-eastern part of the Pannonian basin. The authors present evidence for Late Miocene transpressional strike slip faulting in both areas and discuss inferences for a $\mathrm{N}$ to NE-oriented regional compression. Finite-element stress modelling is presented to quantify the relationships between stress field orientation and structural patterns in the two selected areas. Sanders et al. review the structural and subsidence history of the Neogene Transylvanian basin and its relation to the tectonic and erosion history of the surrounding Carpathian mountains inferred from fission track data. The authors present the results from mass balance calculations of material eroded from the mountain belts and sediments deposited in the basin. Sanders et al. quantify the effect of lithosphere loading and unloading as a consequence of mass transfer by tectonic and erosional processes using numerical modelling technique. They provide evidence for a Pliocene through Recent isostatic uplift of the basin surface between 300 and 500 metres.

\subsection{Eastern Alps/Carpathians junction zone}

The next two papers focus on the Eastern Alps/Carpathians junction area. Dunkl and Frisch present constraints from thermochronology on the Late Cenozoic exhumation history along the Alpine and West Carpathian margins of the Pannonian basin. The thermochronology data are integrated by these authors with results from seismic, structural and sedimentology evidence for Late Miocene-Pliocene erosional phases. The authors argue in favour of a magnitude in the range of $1-1.5 \mathrm{~km}$ for the Post-Middle Miocene sediment removal in the area. Székely et al. investigate the neotectonic movements and their geomorphic response in the region of the Eastern Alps. These authors focus on evidence from surface parameters and stress patterns. The inferred vertical motions are connected to the effects of an isostatic response to active plate convergence and strain partitioning as well as to effects of rebound to Quaternary deglaciation and ice-induced erosion. The authors suggest a correlation between surface ruggedness and denudation history, combining an analysis of Digital Elevation Models and fission track data.

\subsection{Western Carpathians}

The next two papers deal with the area of the Western Carpathians. Kováč et al. review the seismic activity and neotectonic evolution of the Western Carpathians. The authors argue for a close connection between seismic activity, crustal rheology and inherited structural patterns in the brittle upper crust. Kováč et al. discuss the implications of their findings for the seismic hazard assessment of the area. 


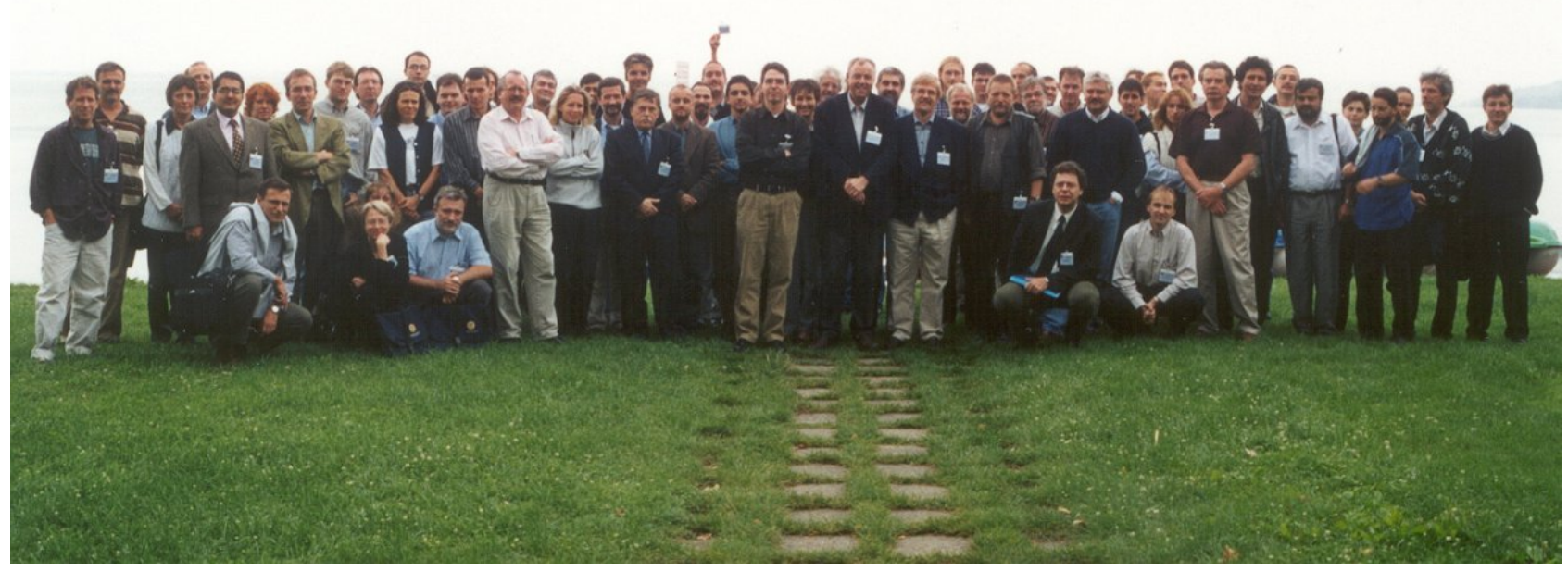

Fig. 3. Group picture of the participants of the Stephan Mueller Conference held in Balatonfüred, Hungary, 22-26 September 2001.

Zuchiewicz et al. (this volume) review the Late Miocene to Present structural development of the Polish segment of the outer Carpathians. These authors point to a major control by normal faulting and block uplift on Late Neogene structural development, whereas the Quaternary structural development was mainly controlled by compressional stresses. The Pliocene-Quaternary tectonics of the area is interpreted in terms of a dominant character of thin-skinned deformation. Steepening of frontal thrusts due to lateral compression within the overthrusted flysch nappes appears to be consistent with the results of recent breakout and GPS studies.

\subsection{Pannonian basin}

The final set of six papers focuses on the intraplate deformation of the Pannonian basin. Síkhegyi presents the analysis of active structural evolution of the western and central parts of the Pannonian basin inferred from geomorphological and hydrographical data and the analysis of genetic types of Quaternary deposits. The author suggests that present-day deformation in the area is likely to take place in the form of NE to ENE drift of lithospheric segments towards the interior of the Pannonian basin. Lopes Cardozo et al. present results from paleostress analysis in the north-eastern margin of Lake Balaton. These authors argue in favour of a scenario based on the inferred neotectonic stress field, strikeslip reactivation, geomorphology and seismicity data, invoking a confined strike-slip fault propagation of a pre-existing fault. Csontos et al. present the results of a structural analysis of the SW Pannonian inselbergs (Mecsek and Villány Mts.), employing paleomagnetic investigations, interpretation of seismic profiles and outcrop studies. On the base of their findings, the authors revise the previous interpretations for rigid block behaviour of the North Pannonian (ALCAPA) and South Pannonian (Tisza) terranes. Lórincz et al. review the neotectonics of the Mid-Hungarian mobile belt located at the boundary of these two terranes comprising the underlying lithosphere of the basin system. The authors present the results of a detailed tectonic analysis carried out on the base of an integrated interpretation of seismic reflection data and borehole information. These authors argue in favour of a major clockwise rotation of the maximum and minimum horizontal stress axes during the Neogene through Quaternary, relating it to the shift of the termination of subduction along the Carpathian arc. Timár and Rácz discuss the effect of neotectonic processes on the flood hazard of the Tisza region in eastern Hungary. The Tisza river flows in an area of continuous Quaternary subsidence, with major sediment influx from Carpathian rivers. The authors discuss the connection between temporal and spatial variations in subsidence and the impact of increased sediment compaction caused by water and hydrocarbon exploitation after the river regulation works. A detailed digital elevation model is presented by the authors offering a valuable tool for flood control reassessment. The final paper by Marović et al. concentrates on recent tectonic activity in the area of the Serbian part of the Pannonian basin and its southern rim from the end of Pliocene up to present times. The authors show evidence for ongoing subsidence in the basin areas occurring simultaneously with ongoing uplift along the rim of the basin. The authors favour an interpretation in terms of late-stage compressional activity in the region.

The papers in this volume illustrate the interdisciplinary nature of research on lithosphere and surface processes feedback in the Pannonian Basin and Alpine/Carpathian System. The volume also demonstrates the high level of the efforts made in the last decades on the collection of substantial highquality data sets needed to constrain process models. The 
next steps in this rapidly emerging field of Environmental Earth System research will directly involve some of the best young researchers from the area utilising and expanding existing links developed over the last ten years, through the Marie Curie Centre for Integrated Sedimentary Basin System studies EUROBASIN. This can only be realised through continued dedicated efforts, mobilising and developing research expertise on a topic of great fundamental and societal importance.

Acknowledgements. We thank all the reviewers for rigorous and constructive reviews of the papers submitted to this volume. The European Geoscience Union is thanked for excellent co-operation in the production of this volume. Karen Leever and Sandra Merten are thanked for editorial assistance. Major efforts by the Eötvös University Budapest and the Hungarian Academy of Sciences, involved in the organisation of the EGS St. Mueller Conference in Balatonfüred, Hungary are gratefully acknowledged. The European Union is thanked for the financial support provided for Central and Eastern European participants at the conference (grant agreement ICA1-CT-2001-60006). We are indebted to the Hungarian National Science Fund OTKA for their financial assistance (project no. T034928). Thanks are due to the Netherlands Research Centre for Integrated Solid Earth Science (ISES) for financial and logistic support. The work of G. Bada was partially funded by the Z. Magyary scholarship of the Ministry of Education, Hungary. Netherlands Research Centre for Integrated Solid Earth Science (ISES) contribution 2002.0710.

\section{References}

Andeweg, B. and Cloetingh, S. A. P. L.: Flexure and unflexure of the North Alpine German-Austrian Molasse basin: constraints from forward tectonic modelling. Geol. Soc. Lond. Spec. Publ., 134, 403-422, 1998.

Bada, G., Cloetingh, S. A. P. L., Gerner, P., and Horváth, F.: Sources of recent tectonic stress in the Pannonian region: inferences from finite element modelling. Geophys. J. Int., 134, 87-101, 1998.

Bada, G., Horváth, F., Cloetingh, S. A. P. L., Coblentz, D. D., and Tóth, T.: Role of topography-induced gravitational stresses in basin inversion: the case study of the Pannonian basin. Tectonics, 20, 343-363, 2001.

Bally, A. W. and Snelson, S.: Realms of subsidence. Can. Soc. Petrol. Geol. Memoir, 6, 9-94, 1980.

Ciulavu, D.: Tertiaty tectonics of the Transylvanian basin. $\mathrm{PhD}$ thesis, Vrije Universiteit Amsterdam, the Netherlands, 154 p, 1999.

Cloetingh, S. A. P. L. and Burov, E. B.: Thermomechanical structure of European continental lithosphere: constraints from rheological profiles and EET estimates. Geophys. J. Int., 124, 695-723, 1996.

Cloetingh, S.A.P.L. and Lankreijer, A.: Lithospheric memory and polyphase deformation of the Pannonian basin system. Mar. Petrol. Geol., 18, 3-11, 2001.

Cloetingh, S. A. P. L., Sassi, W., and Horváth, F., (Eds.): The origin of sedimentary basins: inferences from quantitative modelling and basin analysis. Tectonophysics, 226, 1-518, 1993.

Cloetingh, S. A.P. L., Lankreijer, A., Nemčok, M., Neubauer, F., and Horváth, F., (Eds.). Sedimentary basins and hydrocarbon habitat at the margin of the Pannonian Basin System. Mar. Petrol. Geol., 18, 1-177, 2001.

Csontos, L.: Tertiary teconic evolution of the Intra-Carpathian area: a review. Acta Vulcanol., 7, 1-13, 1995.
Ellouz, N. and Roca, E.: Palinspastic reconstruction of the Carpathians and adjacent areas since the Cretaceous: a quantitative approach. Peri-Tethys Memoir, 1, dit. Technip, Paris, 51-78, 1994.

Fodor, L., Csontos, L., Bada, G., Benkovics, L., and Györfi, I.: Tertiary tectonic evolution of the Carpatho-Pannonian region: a new synthesis of paleostress data. Geol. Soc. Lond. Spec. Publ., 156, 295-334, 1999.

Gerner, P., Bada, G., Dövényi, P., Müller, B., Concescu, M., Cloetingh, S. A.P.L., and Horváth, F.: Recent tectonic stress and crustal deformation in and around the Pannonian basin: data and models. Geol. Soc. Lond. Spec. Publ., 156, 269-294, 1999.

Horváth, F.: Towards a kinematic model for the formation of the Pannonian basin. Tectonophysics, 226, 333-357, 1993.

Horváth, F. and Cloetingh, S. A. P. L.: Stress-induced late stage subsidence anomalies in the Pannonian basin. Tectonophysics, 266, 287-300, 1996.

Horváth, F. and Tari, G.: The IBS Pannonian basin project: A review of the main results and their bearings on hydrocarbon exploration. Geol. Soc. London Spec. Publ., 156, 195-213, 1999.

Horváth, F., Dövényi, P., Szalay, Á., and Royden, L. H.: Subsidence, thermal, and maturation history of the Great Hungarian Plain. AAPG Memoir, 45, 355-372, 1988.

Huismans, R. S., Podladchikov, Y. Y. and Cloetingh, S. A. P. L.: Dynamic modelling of the transition from passive to active rifting, application to the Pannonian basin. Tectonics, 20, 1021-1039, 2001.

Juhász, E., Phillips, L., Müller, P., Ricketts, B., Tóth-Makk, Á., Lantos, M., and Kovács, L. Ó.: Late Neogene sedimentary facies and sequences in the Pannonian basin, Hungary. Geol. Soc. Lond. Spec. Publ., 156, 335-356, 1999.

Lankreijer, A., Kováč, M., Cloetingh, S. A.P.L., Pitonak, P., Hloška, M., and Biermann, C.: Quantitative subsidence analyses and forward modelling in the Vienna and Danube basins. Tectonophysics, 252, 470-484, 1995.

Lankreijer, A., Bielik, S., Cloetingh, S. A.P.L., and Majcin, D.: Rheology predictions across the Western Carpathians, Bohemian Massif and the Pannonian basin: implications for tectonic scenarios. Tectonics, 18: 1139-1153, 1999.

Maţenco, L. and Bertotti, G.: Tertiary tectonic evolution of the external East Carpathians (Romania). Tectonophysics, 316, 255286, 2000.

Maţenco, L., Bertotti, G., Dinu, C., and Cloetingh, S. A. P. L.: Tertiary tectonic evolution of the external South Carpathians and the adjacent Moesian platform (Romania). Tectonics, 16, 896-911, $1997 \mathrm{a}$.

Maţenco, L., Zoetemeijer, R., Cloetingh, S. A.P. L., and Dinu, C.: Tectonic flexural modelling of the Romanian Carpathians foreland system. Tectonophysics, 282, 147-166, $1997 \mathrm{~b}$.

Meulenkamp, J. E., Kováč, M., and Cicha, I.: On Late Oligocene to Pliocene depocentre migration and the evolution of the Carpathian-Pannonian System. Tectonophysics, 266, 301-317, 1996.

Neubauer, F., Cloetingh, S. A.P. L., Dinu, C., and Mocanu, V. (Eds.): Tectonics of the Alpine-Carpathian-Pannonian region (ALCAPA). Tectonophysics, 272, 1-334, 1997.

Royden, L. H.: Late Cenozoic tectonics of the Pannonian basin system. AAPG Memoir, 45, 27-48, 1988.

Royden, L. and Horváth, F., (Eds.): The Pannonian basin: A case study in basin evolution. AAPG Memoir, 45, 1-394, 1988.

Sacchi, M., Horváth, F., and Magyari, O.: Role of unconformitybounded units in the stratigraphy of the continental record: a case 
study from the Late Miocene of the western Pannonian basin, Hungary. Geol. Soc. London Spec. Publ., 156, 357-390, 1999.

Sachsenhofer, R. F., Lankreijer, A. C., Cloetingh, S. A.P.L., and Ebner, F.: Subsidence analysis and quantitative basin modelling in the Styrian basin (Pannonian Basin System, Austria). Tectonophysics, 272, 175-198, 1997.

Sanders, C. A. E., Andriessen, P. A. M., and Cloetingh, S. A. P. L.: Life cycle of the East Carpathian Orogen: erosion history of a doubly vergent critical wedge assessed by fission track thermochronology. J. Geophys. Res., 104. 29 095-29 112, 1999.

Sclater, J. G., Royden, L., Horváth, F., Burchfiel, B. C., Semmken, S., and Stegena, L.: The formation of intra-Carpathian basins as determined from subsidence data. Earth Planet. Sci. Letters, 51, 139-162, 1980.

Szafián, P., Horváth, F., and Cloetingh, S. A. P. L.: Gravity constraints on the crustal structure and slab evolution along a Transcarpathian transect. Tectonophysics, 272, 233-248, 1997.

Szafián, P., Tari, G., Horváth, F., and Cloetingh, S. A. P. L.: Crustal structure of the Alpine-Pannonian transition zone: a combined seismic and gravity study. Int. J. Earth Sciences, 88, 98-110, 1999.

Tari, G.: Alpine tectonics of the Pannonian basin. PhD thesis, Rice University, Houston, Texas, 501 p, 1994.

Tari, G., Dövényi, P., Dunkl, I., Horváth, F., Lenkey, L., Stefanescu, M., Szafián, P., and Tóth, T.: Lithospheric structure of the Pan- nonian basin derived from seismic, gravity and geothermal data. Geol. Soc. London Spec. Publ., 156, 215-250, 1999.

Vakarcs, G., Vail, P. R., Tari, G., Pogácsás, Gy., Mattick, R. E., and Szabó, A.: Third-order Miocene-Pliocene depositional sequences in the prograding delta complex of the Pannonian basin. Tectonophysics, 240, 81-106, 1994.

Van Balen, R. T., Lenkey, L., Horváth, F., and Cloetingh, S. A. P. L.: Two-dimensional modelling of stratigraphy and fluid flow in the Pannonian basin. Geol. Soc. Lond. Spec. Publ., 156, 391-414, 1999.

Wenzel, F., Achauner, U., Enescu, D., Kisling, E., Russo, R., Mocanu, V., and Musacchio, G.: Detailed look at final stage of slab break-off is target of study in Romania. EOS, 79(48), 1998.

Willingshofer, E., van Wees, J. D., Cloetingh, S. A.P.L., and Neubauer, F.: Thermomechanical consequences of Cretaceous continent-continent collision in the Eastern Alps (Austria): insights from two-dimensional modelling. Tectonics, 18, 809-826, 1999.

Wortel, M. J. R. and Spakman, W.: Subduction and slab detachment in the Mediterranean-Carpathian region. Science, 290, 19101917, 2000.

Zoetemeijer, R., Tomek, C., and Cloetingh, S. A. P. L.: Flexural expression of European continental lithosphere under the western outer Carpathians. Tectonics, 18, 843-861, 1999. 